\title{
Effect of Biochar, Farmyard Manure and Nitrogen Fertilizers on Soil Chemical Properties in Sinana District, South Eastern Oromia, Ethiopia
}

\author{
Abdurahman Husien ${ }^{1,}$, Bobe Bedadi ${ }^{2}$, Nigussie Dechassa ${ }^{3}$ \\ ${ }^{1}$ Sinana Agricultural Research Center, Bale Robe, Ethiopia \\ ${ }^{2}$ School of Natural Resource and Environmental Science, Haramaya University, Dire Dawa, Ethiopia \\ ${ }^{3}$ School of Plant Science, Haramaya University, Dire Dawa, Ethiopia \\ Email address: \\ abdurahmanh2010@gmail.com (A. Husien) \\ ${ }^{*}$ Corresponding author
}

\section{To cite this article:}

Abdurahman Husien, Bobe Bedadi, Nigussie Dechassa. Effect of Biochar, Farmyard Manure and Nitrogen Fertilizers on Soil Chemical Properties in Sinana District, South Eastern Oromia, Ethiopia. International Journal of Applied Agricultural Sciences.

Vol. 3, No. 6, 2017, pp. 148-153. doi: 10.11648/j.ijaas.20170306.12

Received: July 26, 2017; Accepted: August 7, 2017; Published: November 10, 2017

\begin{abstract}
Integrated soil fertility management could be a useful tool to maintain and improving soil fertility. Therefore, the experiment was conducted with the objective of investigating the influence of biochar, farmyard manure, and mineral nitrogen fertilizer on soil chemical properties. The disturbed soil samples were collected from five locations of each plot at optimum moisture conditions to a depth of $20 \mathrm{~cm}$ at the start of the experiment, after six months of farmyard manure and biochar treatments application. The treatments consisted of two levels of farmyard manure $\left(0\right.$ and 6 tons ha $\left.{ }^{-1}\right)$, three levels of biochar $(0$, 5 , and 10 tons ha $\left.{ }^{-1}\right)$ and three levels of nitrogen $\left(0,23\right.$ and $\left.46 \mathrm{~kg} \mathrm{~N} \mathrm{ha}^{-1}\right)$. The results revealed that the interaction effects of biochar, farmyard manure, and mineral nitrogen fertilizer significantly $(\mathrm{P}<0.001)$ influenced the soil chemical properties of major contents of soil available potassium, nitrate nitrogen and ammonium nitrogen after six months. Similarly, the analysis of variance showed that the interaction effect of biochar and farmyard manure levels significantly $(\mathrm{P}<0.05)$ influenced soil reaction $(\mathrm{pH})$ and $\mathrm{CEC}$. However, the interaction effect of biochar, farmyard manure and nitrogen levels and that of farmyard manure and biochar levels as well as biochar and nitrogen levels on soil available phosphorus were non-significant. Generally, the availability of plant nutrients concentration in the soil solution before treatments of farmyard manure and biochar application was lower than that of after six months. Likewise, farmer should be advised to add small amount of mineral fertilizer to farmyard manure and biochar to improve soil properties and enhance soil productivity and quality.
\end{abstract}

Keywords: Biochar, Farmyard Manure, Soil Solution, Chemical and Soil Reaction

\section{Introduction}

Soil is the most important natural resources, because it is a primary medium for the growth of food and fodder. The use of organic materials as fertilizers for crop production has received attention particularly recently for sustainable crop production [1]. According to [2], many soils in the highlands of Ethiopia are poor in available plant nutrients and organic matter content. In addition to this previously, only nitrogen $(\mathrm{N})$ and phosphorus $(\mathrm{P})$ were considered to be the limiting nutrients in Vertisols of Ethiopia [3].
The application of farmyard manure (FYM) to soil has been practiced for many centuries and its application to soil have increased crop yield, improved soil fertility, increased soil organic matter, increased microbiological activities and improved soil structure for sustainable agriculture [4]. Likewise, biochar application has received a growing interest as a sustainable technology to improve highly weathered or degraded soils [5]. Similarly, According to [6], biochar application significantly increased soil carbon (C), phosphorus (P) and potassium (K) by 54.02, 61.39 and $18.41 \%$, respectively.

The soils of Bale highlands including Sinana area are dominantly Vertisols, Cambisols and Phaeozems with poor 
structure, low infiltration capacity and develop deep cracks in dry seasons [7]. Therefore, it is generally accepted that improved soil conditions associated with manure and biochar application lead to changes in soil physical and chemical properties. Therefore, this study was undertaken with the objectives of investigate the influence of biochar, farmyard manure and nitrogen fertilizer on soil chemical properties.

\section{Materials and Methods}

\subsection{Description of the Study Area}

The experiment was conducted during the 2015 main cropping season at Selka Kebele of Sinana district which is located in Bale zone of Oromia Regional State with the geographic coordinates of $07^{\circ} 04^{\prime} 248^{\prime \prime} \mathrm{N}$ to $07^{\circ} 04^{\prime} 256^{\prime \prime} \mathrm{N}$ and $040^{\circ} 11^{\prime} 137^{\prime \prime} \mathrm{E}$ to $040^{\circ} 11^{\prime} 154^{\prime \prime} \mathrm{E}$ at a distance of about $456 \mathrm{~km}$ Southeast of Addis Ababa and at an altitude of 2400 $\mathrm{m}$ above sea level (Figure 1). The area is characterized by high altitude, sub humid climate with bimodal rainfall pattern, According to Sinana Agricultural Research Center Meteorology Station records from 1993 to 2015, the long-term precipitation ranges from 710.10 to $1566.30 \mathrm{~mm}$ with an annual average of $1149.72 \mathrm{~mm}$. The area has bimodal rainfall pattern with the first rainy season start from March and taper off in July, while the second rains fall between August and December (Figure 2). The area receives rainfall of 320.05 to $861.39 \mathrm{~mm}$ during the first rainy season (March to July) and 353.38 to $867.90 \mathrm{~mm}$ during the main season (August to December). The mean annual maximum temperature is $20.96^{\circ} \mathrm{C}$ and the monthly values range between $19.39^{\circ} \mathrm{C}$ in October and $22.85^{\circ} \mathrm{C}$ in February. The mean annual minimum temperature is $9.67^{\circ} \mathrm{C}$ and the monthly values range between $7.93^{\circ} \mathrm{C}$ in December and $10.79^{\circ} \mathrm{C}$ in May. The coldest month is December whereas February is the hottest month (Figure 2).

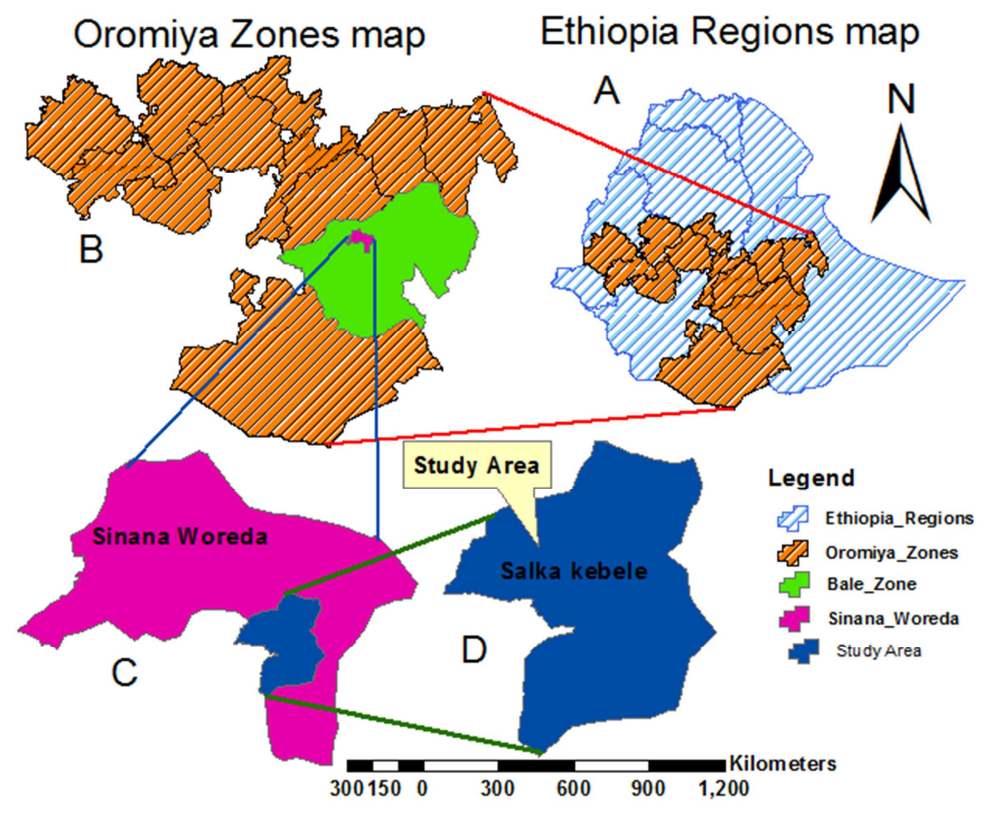

Figure 1. Maps of the study area.

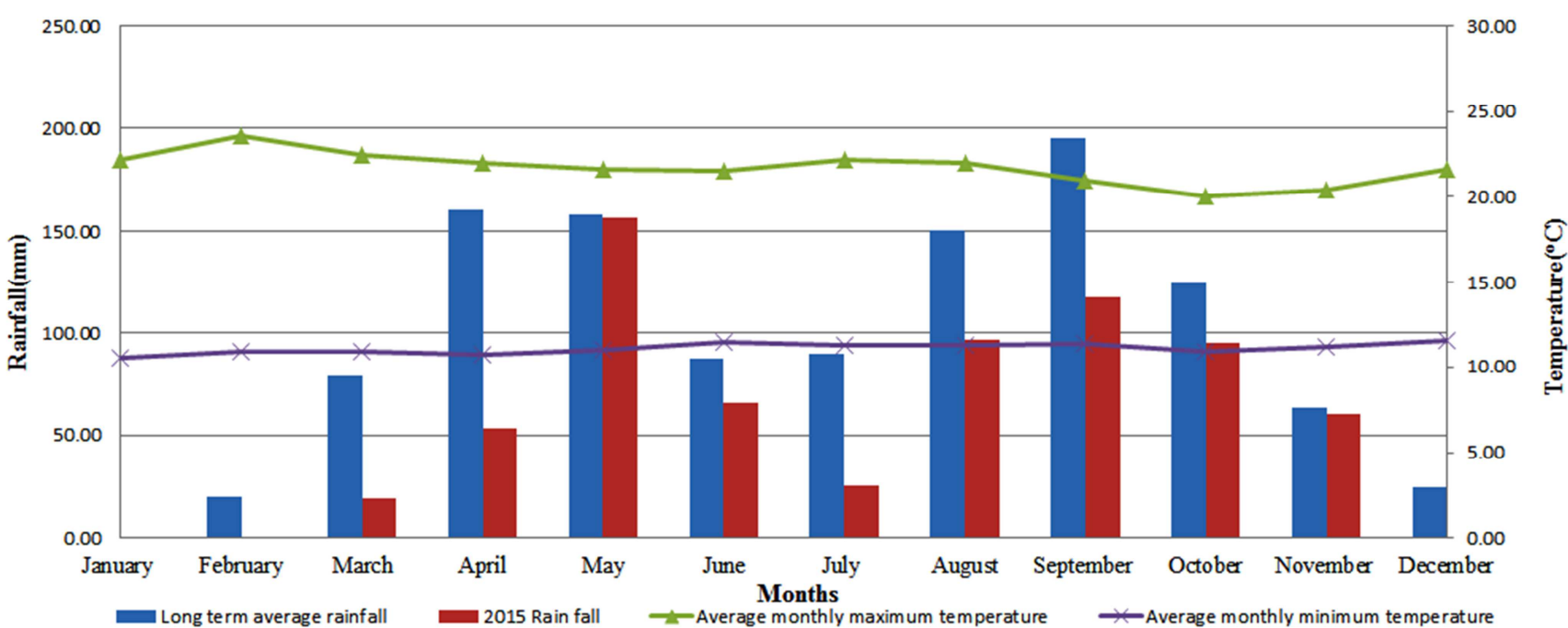

Figure 2. Monthly rainfall (2015), long term average rainfall, maximum and minimum monthly average temperature of Sinana Agricultural Research Center. 


\subsection{Data Collection}

\subsubsection{Soil Samples Collection and Preparation}

Disturbed soil samples were collected from five locations of each plot at optimum moisture conditions to a depth of $20 \mathrm{~cm}$ using augur prior to the start of the experiment, after six months of farmyard manure and biochar treatments application. From these, composite samples of $1 \mathrm{~kg}$ soil were made for each plot. The samples were taken to the laboratory, air-dried, crushed, and sieved to pass through a $2 \mathrm{~mm}$ and $1 \mathrm{~mm}$ mesh.

\subsubsection{Soil Sample Analysis}

Laboratory analyses were conducted at Sinana Agricultural Research Center, Zeway Soil Agricultural Research Center and Horticoop Ethiopia for selected soil physico-chemical parameters following standard laboratory procedures.

\subsubsection{Soil Chemical Analysis}

Soil $\mathrm{pH}$ was potentiometrically measured in the supernatant suspension of 1:2.5 soils: water and potassium chloride solution ratio [8]. Soil organic carbon content of the soil was determined by potassium dichromate wet oxidation procedure [9]. Soil organic matter was calculated from soil organic carbon by multiplying with a coefficient of 1.724 . Total nitrogen content of the soil was determined by wet digestion procedures of the Kjeldahl method [8]. C: $\mathrm{N}$ ratio was calculated from organic carbon and total nitrogen by dividing soil organic carbon with soil total nitrogen. The available phosphorus content of soils was determined by $0.5 \mathrm{M}$ sodium bicarbonate extraction procedures [10]. Available potassium (K) was determined by ammonium acetate extraction-flame photometry procedure [11]; The cations exchange capacity of the soil (CEC) was measured after saturating the soil with $1 \mathrm{~N}$ ammonium acetate $\left(\mathrm{NH}_{4} \mathrm{OAc}\right)$ and displacing it with $1 \mathrm{~N} \mathrm{NaOAc} \mathrm{[12];} \mathrm{Soil} \mathrm{nitrate} \mathrm{nitrogen} \mathrm{and}$ ammonium nitrogen ions were determined by steam distillation (ISO 7890-1) and (ISO 7150-1) respectively.
Table 1. Soil chemical and physical properties of the experimental site before treatment application

\begin{tabular}{lll}
\hline Soil Chemical Properties & Results & Units \\
\hline Soil Reaction $(\mathrm{pH})$ & 6.64 & - \\
Phosphorus & 12.68 & $\mathrm{mg} / \mathrm{kg}$ soil \\
Potassium & 2.65 & $\mathrm{cmol} / \mathrm{kg}$ soil \\
Calcium & 25.47 & $\mathrm{cmol}_{\mathrm{c}} / \mathrm{kg}$ soil \\
Magnesium & 4.61 & $\mathrm{cmol} / \mathrm{kg}$ soil \\
Sodium & 0.06 & $\mathrm{cmol} / \mathrm{kg}$ soil \\
Sulfur & 0.50 & $\mathrm{mg} / \mathrm{kg}$ soil \\
Iron & 32.64 & $\mathrm{mg} / \mathrm{kg}$ soil \\
Manganese & 221.67 & $\mathrm{mg} / \mathrm{kg}$ soil \\
Zinc & 0.22 & $\mathrm{mg} / \mathrm{kg}$ soil \\
Boron & 0.19 & $\mathrm{mg} / \mathrm{kg}$ soil \\
Copper & 4.51 & $\mathrm{mg} / \mathrm{kg}$ soil \\
Molybdenum & 0.10 & $\mathrm{mg} / \mathrm{kg}$ soil \\
Total Nitrogen & 0.18 & $\%$ \\
Cation Exchange Capacity & 53.93 & $\mathrm{cmol} / \mathrm{kg}$ soil \\
Aluminum & 6.32 & $\mathrm{cmol} / \mathrm{kg}$ soil \\
Organic Matter & 1.79 & $\%$ \\
Soil Physical properties & & $\%$ \\
Soil texture (\%) & & $\mathrm{Clayey}$ \\
Clay & 56 & \\
Silt & 35 & $\%$ \\
Sand & 9 & $\%$ \\
Soil textural class & Clay & \\
\hline
\end{tabular}

\subsubsection{Biochar, Farmyard Manure Chemical Composition and Pre Soil Analysis}

A composite sample was made from the prepared treatment of biochar, farmyard manure and pretreatment application soil samples. A separate sample was air-dried; ground using a pestle and mortar and allowed to pass through a $2 \mathrm{~mm}$ and 1 $\mathrm{mm}$ sieve. The chemical analyses of the farmyard manure, biochar and pretreatment application soil samples were conducted using the Mehlich-III multi-nutrient extraction procedure [13] Using Atomic Absorption Spectroscopy and spectrophotometer

Table 2. Chemical compositions of farmyard manure and biochar applied as a treatment.

\begin{tabular}{|c|c|c|c|}
\hline Description of Parameter & Biochar & Farmyard manure & Units \\
\hline Soil Reaction & 9.81 & 8.67 & - \\
\hline Ammonium & 42.56 & 0.04 & $\mathrm{mg} / \mathrm{kg}$ soil \\
\hline Nitrate & 2867.42 & 291.91 & $\mathrm{mg} / \mathrm{kg}$ soil \\
\hline Potassium & 16.10 & 9.79 & $\mathrm{cmol}_{\mathrm{c}} / \mathrm{kg}$ soil \\
\hline Calcium & 0.11 & 0.61 & $\mathrm{cmol}_{\mathrm{c}} / \mathrm{kg}$ soil \\
\hline Magnesium & 0.04 & 0.18 & $\mathrm{cmol}_{\mathrm{c}} / \mathrm{kg}$ soil \\
\hline Sulfur & 415.28 & 19.90 & $\mathrm{mg} / \mathrm{kg}$ soil \\
\hline Silicon & 59.48 & 5.04 & $\mathrm{mg} / \mathrm{kg}$ soil \\
\hline Iron & 1.46 & 0.58 & $\mathrm{mg} / \mathrm{kg}$ soil \\
\hline Manganese & 0.09 & 0.06 & $\mathrm{mg} / \mathrm{kg}$ soil \\
\hline Zinc & 0.02 & 0.02 & $\mathrm{mg} / \mathrm{kg}$ soil \\
\hline Boron & 0.48 & 0.04 & $\mathrm{mg} / \mathrm{kg}$ soil \\
\hline Copper & 0.04 & 0.07 & $\mathrm{mg} / \mathrm{kg}$ soil \\
\hline Molybdenum & 0.31 & 0.02 & $\mathrm{mg} / \mathrm{kg}$ soil \\
\hline Cation Exchange Capacity & 61.32 & 54.94 & $\mathrm{cmol}_{\mathrm{C}} / \mathrm{kg}$ soil \\
\hline
\end{tabular}

\subsubsection{Statistical Data Analysis}

The effects of treatments on soil chemical properties and the collected data were subjected to analysis of variance (ANOVA) using general linear model (GLM) procedures of statistical 
analysis system of computer software [14] and significantly differing means were separated using the Duncan`s multiple range test (DMRT). Least significant difference (LSD) test was involved to compare among means separated by DMRT.

\section{Results and Discussion}

\subsection{Post-Harvest Soil Chemical Properties}

Soil reaction $(\mathrm{pH})$, organic carbon and available phosphorus

The analysis of variance showed that the interaction effect of biochar, farmyard manure and nitrogen levels and that of farmyard manure and nitrogen levels as well as biochar and nitrogen levels on soil reaction were non- significant. However, that of farmyard manure and biochar on soil reaction was significant $(\mathrm{P}<0.05)$ (Table 3$)$.

As the results of mean of main effects show that there was slight increase in soil reaction with the increase in biochar levels $\left(0,5\right.$ and 10 ton $\left.\mathrm{ha}^{-1}\right)$ from the control treatment 0.13 and 0.2 biochar levels respectively. This study in line with [15] finding application of charcoals from burned biomass had demonstrated well their ability to raise soil $\mathrm{pH}$ in previous.

The analysis of variance showed that none of the interaction effect of the treatments was significant on soil organic carbons. Likewise, the main effects of nitrogen levels on soil organic carbons were non- significant. However, that of biochar levels on soil organic carbons was highly significant $(\mathrm{P}<0.001)$ as well as farmyard manure levels on soil organic carbons was significant $(\mathrm{P}<0.05)$ (Table 3$)$.

As the analyzed results shows that the soil organic carbon increase with the increase of biochar $(0,5$ and 10 ton ha- 1$)$ by 0.07 and $0.14 \%$ and farmyard manure rate $(0$ and 6 ton ha- 1$)$ by $0.08 \%$ over the control treatment respectively; this may be affected by the decomposing rate of organic material applied to the soils. In line with this finding of [16] who observed a remarkable increase in organic carbon and organic matter content of the soil after the application of biochar and attributed it to the fact that biochar is a recalcitrant organic material. Similarly, [17] also concluded that FYM application level of 30 and $60 \mathrm{Mg} \mathrm{ha}^{-1}$ increased organic matter contents on both row and inter row tracks significantly.

The analysis of variance showed that the interaction effect of biochar, farmyard manure and nitrogen levels and that of farmyard manure and biochar levels as well as biochar and nitrogen levels on soil available phosphorus were non-significant. However, that of farmyard manure and nitrogen levels on soil available phosphorus was significant $(\mathrm{P}<0.05)$.

As the analyzed results shows that the soil available phosphorus increase with the increase of biochar $(0,5$ and 10 ton $\left.\mathrm{ha}^{-1}\right)$ by 35.44 and $43.29 \%$ and farmyard manure rate $(0$ and 6 ton $\mathrm{ha}^{-1}$ ) by $18.70 \%$ over the control respectively. Therefore from this point of view the levels of biochar affect soil available phosphorus than the levels of farmyard manure; this is due to the effects of biochar on soil reaction than farmyard manure which increases the mobility of phosphate in the soil solution. In line with this according to the study conducted by According to [18], the observed increase in available phosphorus due to application of biochar could be due to the presence of high phosphorous in the maize stalk.

Table 3. The main effect of biochar, farmyard manure and nitrogen levels on soil reaction, soil organic carbon (\%) and available phosphorus after six months

\begin{tabular}{|c|c|c|c|}
\hline FYM (ton ha-1) & pH: $\mathrm{H}_{2} \mathrm{O}$ & OC $(\%)$ & Ava. P (mg kg ${ }^{-1}$ soil) \\
\hline 0 & 7.34 & $1.71^{\mathrm{b}}$ & $7.52^{\mathrm{b}}$ \\
\hline 6 & 7.36 & $1.79^{\mathrm{a}}$ & $9.25^{\mathrm{a}}$ \\
\hline $\begin{array}{l}\operatorname{LSD}_{(0.05)} \\
\text { Biochar (ton } \text { ha }^{-1}\end{array}$ & NS & 0.05 & 1.04 \\
\hline 0 & $7.24^{\mathrm{c}}$ & $1.68^{\mathrm{c}}$ & $5.83^{\mathrm{b}}$ \\
\hline 5 & $7.37^{\mathrm{b}}$ & $1.75^{\mathrm{b}}$ & $9.03^{\mathrm{a}}$ \\
\hline 10 & $7.44^{\mathrm{a}}$ & $1.82^{\mathrm{a}}$ & $10.28^{\mathrm{a}}$ \\
\hline \multicolumn{4}{|c|}{ Nitrogen $\left(\mathrm{Kg} \mathrm{N} \mathrm{ha}^{-1}\right)$} \\
\hline 0 & 7.35 & 1.73 & 8.08 \\
\hline 23 & 7.35 & 1.74 & 8.11 \\
\hline 46 & 7.36 & 1.78 & 8.96 \\
\hline $\operatorname{LSD}_{(0.05)}$ & NS & NS & NS \\
\hline $\mathrm{CV}(\%)$ & 0.85 & 4.72 & 22.41 \\
\hline
\end{tabular}

Means followed by the same letter with in the same column of the respective treatment are not significantly different $(\mathrm{P} \leq 0.05)$ according to Duncan's Multiple Range Test, FYM = Farmyard manure, CV = Coefficient of variation, LSD = Least Significant differences, NS = not Significant.

Soil total nitrogen, cation exchange capacity (CEC) and $\mathrm{C}$ : $\mathrm{N}$ ratio.

The analysis of variance showed that the interaction effect of biochar, farmyard manure and nitrogen levels on soil total nitrogen were non- significant. However, that of farmyard manure and nitrogen level as well as biochar and nitrogen levels on soil total nitrogen was significant $(\mathrm{P}<0.05)$. Likewise, that of farmyard manure and biochar on soil total nitrogen was highly significant $(\mathrm{P}<0.001)$ (Table 4$)$.

As the analyzed results revealed that the interaction mean of biochar and farmyard manure increases with the increase in the biochar rates $\left(0,5\right.$ and 10 ton $\left.\mathrm{ha}^{-1}\right)$ by the 0 ton $\mathrm{ha}^{-1}$ farmyard manure; however, the interaction mean between farmyard manure and biochar rates increments there was no regularity of mean interaction increment. Total nitrogen measures the total amount of nitrogen present in the soil, much of which is held in organic matter and is not immediately available to plants. It may be mineralized to be in available forms.

The analysis of variance showed that the interaction effect of biochar, farmyard manure and nitrogen levels and that of 
farmyard manure and nitrogen levels as well as biochar and nitrogen levels on cation exchange capacity (CEC) were nonsignificant. However, that of farmyard manure and biochar on cation exchange capacity $(\mathrm{CEC})$ was significant $(\mathrm{P}<0.05)$ (Table 4).

As the mean interaction indicated that there was an increase in cation exchange capacity (CEC) with the increase in the rate of farmyard manure $\left(0\right.$ and 6 ton $\left.\mathrm{ha}^{-1}\right)$ and biochar $(0,5$ and 10 to $\mathrm{ha}^{-1}$ ) this shows that with the increase in the soil organic matter also increase in cation exchange capacity (CEC). This study in line with cation exchange capacities may increase over short time during aging as an increase in the CEC of aged biochar's compared to fresh ones due to generation of oxygenated surface functional groups by surface oxidation process has previously been reported [16].

The analysis of variance showed that the interaction effect of biochar, farmyard manure and nitrogen levels on $\mathrm{C}$ : $\mathrm{N}$ ratio was non- significant. However, that of farmyard manure and nitrogen levels as well as biochar and nitrogen levels on soil $\mathrm{C}$ : $\mathrm{N}$ ratio was significant $(\mathrm{P}<0.05)$. Likewise that of farmyard manure and biochar on $\mathrm{C}$ : $\mathrm{N}$ ratio was highly significant $(\mathrm{P}<$ 0.001) (Table 4).

As the mean interaction results revealed that with increase rate of biochar there was a decrease of $\mathrm{C}$ : $\mathrm{N}$ Ratio with interaction of control farmyard manure, But the high value $\mathrm{C}$ : $\mathrm{N}$ Ratio was recorded with the of 6 ton $\mathrm{ha}^{-1}$ farmyard manure and 5 ton ha $^{-1}$ biochar which was 13.28 and the lowest value was 10.81 with the mean interaction of 6 ton $\mathrm{ha}^{-1}$ farmyard manure and 10 ton $\mathrm{ha}^{-1}$ biochar. Similar findings according to [19] Increasing the biochar application levels increased the C: $\mathrm{N}$ ratio of the soil and appeared to reduce $\mathrm{N}$ uptake probably because of nitrogen immobilization. This might only be a short-term effect; once the more labile (volatile carbon component) of the biochar is degraded, then this should reduce immobilization. Therefore, the exclusive use of biochar in the absence of $\mathrm{N}$ fertilizer is not encouraged.

Table 4. The interaction effect of farmyard manure and biochar rate on cation exchange capacity, $C: N$ ratio and soil total nitrogen after six months

\begin{tabular}{|c|c|c|c|c|c|c|c|c|c|}
\hline \multicolumn{4}{|l|}{ CEC $\left(\mathrm{cmolc} \mathrm{kg}^{-1}\right)$} & \multicolumn{3}{|c|}{ C:N Ratio } & \multicolumn{3}{|c|}{ TN (\%) } \\
\hline & & & & \multicolumn{6}{|c|}{ Biochar (ton ha $\left.{ }^{-1}\right)$} \\
\hline FYM $\left(\right.$ ton $\left.h^{-1}\right)$ & $\mathbf{0}$ & 5 & 10 & 0 & 5 & 10 & $\mathbf{0}$ & 5 & 10 \\
\hline 0 & $48.88^{\mathrm{a}}$ & $53.62^{b}$ & $55.92^{\text {cd }}$ & $12.49^{\mathrm{bc}}$ & $11.47^{\mathrm{ab}}$ & $10.96^{\mathrm{a}}$ & $0.133^{\mathrm{a}}$ & $0.151^{b}$ & $0.166^{\mathrm{c}}$ \\
\hline 6 & $53.68^{\mathrm{b}}$ & $54.93^{\mathrm{bc}}$ & $57.54^{\mathrm{d}}$ & $11.03^{\mathrm{a}}$ & $13.28^{\mathrm{c}}$ & $10.81^{\mathrm{a}}$ & $0.160^{\mathrm{bc}}$ & $0.136^{\mathrm{a}}$ & $0.172^{\mathrm{c}}$ \\
\hline $\mathrm{SE} \pm$ & & 1.73 & & & 1.087 & & & 0.013 & \\
\hline $\operatorname{LSD}_{(0.05)}$ & & 1.66 & & & 1.041 & & & 0.012 & \\
\hline CV (\%) & & 3.2 & & & 9.3 & & & 8.2 & \\
\hline
\end{tabular}

Means followed by the same letter with in the same column of the respective treatment are not significantly different $(\mathrm{P} \leq 0.05)$ according to Duncan's Multiple Range Test, $\mathrm{FYM}=$ Farmyard manure, $\mathrm{SE}=$ Standard error, $\mathrm{CV}=$ Coefficient of variation, Least Significant differences, $\mathrm{NS}=$ not significant, $\mathrm{CEC}=\mathrm{Cation}$ exchange capacity, $\mathrm{TN}=$ total nitrogen, $\mathrm{C}: \mathrm{N}=$ Carbon to nitrogen.

\subsection{Soil Available Potassium}

The analysis of variance showed that the interaction effect of biochar, farmyard manure and nitrogen levels on Soil Available Potassium were highly significant $(\mathrm{P}<0.001)$ (Table 5).

As the analyzed result of mean interaction revealed that the effect of biochar, farmyard manure and nitrogen levels on soil available potassium were increases with the levels of means interaction increase. Similarly, this study in line with [20] available potassium in soil increased with the application of organic manures which is due to solubilizing action of organic acids produced during farmyard manure decomposition and its higher capacity to hold potassium in available form. Likewise, increase in exchangeable Potassium was recorded by the application of biochar [21].

Generally, the availability of plant nutrient concentration in the soil solution before application of treatments of farmyard manure and biochar were lower than that of after six months, specially NPK which have been mostly required by plants; this might be due to moisture availability, reduction of loss (volatilization and leaching) and the increments of soil organic matter.

Table 5. The interaction effect of farmyard manure, biochar and urea on soil available potassium after six months.

\begin{tabular}{|c|c|c|c|c|}
\hline \multirow[b]{3}{*}{ FYM (ton ha $\left.\mathbf{h a}^{-1}\right)$} & \multicolumn{4}{|c|}{ Soil Available Potassium ( $\mathrm{mg} \mathrm{kg}^{-1}$ soil) } \\
\hline & & \multicolumn{3}{|c|}{ Nitrogen $\left(\mathrm{kg} \mathrm{N} \mathrm{ha}^{-1}\right)$} \\
\hline & Biochar(ton ha $\left.{ }^{-1}\right)$ & 0 & 23 & 46 \\
\hline \multirow{3}{*}{0} & 0 & $147.50^{\mathrm{ab}}$ & $143.85^{\mathrm{a}}$ & $148.74^{\mathrm{ab}}$ \\
\hline & 5 & $166.43^{\mathrm{def}}$ & $172.12^{\text {fgh }}$ & $161.30^{\mathrm{cd}}$ \\
\hline & 10 & $177.90^{\mathrm{i}}$ & $173.97^{\text {ghi }}$ & $167.31^{\mathrm{ef}}$ \\
\hline \multirow[t]{3}{*}{6} & 0 & $152.74^{\mathrm{b}}$ & $165.20^{\text {cde }}$ & $160.09^{\mathrm{c}}$ \\
\hline & 5 & $170.59^{\mathrm{efg}}$ & $168.23^{\mathrm{ef}}$ & $176.39^{\mathrm{hi}}$ \\
\hline & 10 & $184.49^{\mathrm{j}}$ & $174.94^{\text {ghi }}$ & $185.14^{\mathrm{j}}$ \\
\hline $\mathrm{SE} \pm$ & & & 3.11 & \\
\hline $\operatorname{LSD}_{(0.05)}$ & & & 5.17 & \\
\hline $\mathrm{CV}(\%)$ & & & 1.90 & \\
\hline
\end{tabular}

Means followed by the same letter with in the same column of the respective treatment are not significantly different $(\mathrm{P} \leq 0.05)$ according to Duncan's Multiple Range Test, FYM = Farmyard manure, $\mathrm{SE}=$ Standard error, $\mathrm{CV}=$ Coefficient of variation, Least Significant differences, NS $=$ not Significant. 


\section{Conclusion}

The application of Biochar, Farmyard Manure and Nitrogen fertilizer on soil chemical properties after six months of treatments incorporation to the soils showed that none of the interaction effect of the treatments was significant on soil organic carbons. However, that of biochar levels on soil organic carbons was highly significant as well as farmyard manure levels on soil organic carbons was significantly enhanced. Accordingly, the interaction of biochar, farmyard manure and nitrogen levels and that of farmyard manure and biochar levels as well as biochar and nitrogen levels on soil available phosphorus were not increased. However, that of farmyard manure and nitrogen levels on soil available phosphorus was significantly increased. Generally, the interaction of biochar and farmyard manure on cation exchange capacity (CEC) was significant increased. However, as the results of mean of main effects show that there was slight increase in soil reaction with the increase in biochar levels. Recommendations; farmers are advised to add small amount of mineral fertilizer to farmyard manure and biochar to improve soil properties and enhance soil productivity and quality.

\section{Acknowledgements}

The authors would like to thank all staffs of Soil Fertility Improvement and Soil and Water Conservation team of Sinana Agricultural Research Center, for their contribution towards implementation of the study, and Sinana Agricultural Research Centre for providing necessary logistic support in the course of the study. The generous financial assistance from Oromia Agricultural Research Institute is also gratefully acknowledged.

\section{References}

[1] Yang, Huffman, Jong, Kirkwood, MacDonald and Drury. 2007. Residual soil nitrogen in soil landscapes of Canada as affected by land use practices and Agricultural policy scenarios. Land Uses Policy, 24: 89-99.

[2] Tekalign Mamo, C. Richter and B. Heiligtag, 2002. Phosphorus availability studies on ten Ethiopian Vertisols. J. of Agri. and Rural Devt. in the Tropics and Subtropics, 103 (2): 177-183.

[3] Tekalign Mamo, Haque I. and Kamara G. S., Follow one pattern. 1988. P status of some Ethiopia highland Vertisols. PP. 232-249. In: Jutz, S. C., I. HaqueMdntirc (eds.) Soils in Sub-Saharan Africa, ILCA, Addis Ababa, Ethiopia.

[4] Kundu, Bhattacharyya, Parkash, Ghosh and Gupta. 2007. Carbon sequestration and relationship between carbon addition and storage under rain fed soybean-wheat rotation in a sandy loam soil of the India Himalayas. Soil and Tillage Res. 92: 87-95.

[5] Lehmann J. 2007. Bio-energy in the black. Frontiers in Ecology and the Environment 5: 381-387.

[6] Ali, Arif, Jan, Khan and Jones. 2015. Integrated use of biochar: a tool for improving soil and wheat quality of degraded soil under wheat-maize cropping pattern. Pak. J. Bot., 47 (1): 233-240.
[7] Abayneh Esayas and Ashenafi Ali. 2006. Soils of Sinana Agricultural Research Center. Ethiopian Agricultural Research Institute. National Soil Research Center, 43pp.

[8] Motsara and Roy. 2008. Guide to Laboratory Establishment for Plant Nutrient Analysis. Food and Agriculture Organization of the United Nations. Fertilizer and Plant Nutrition Bulletin No. 19. Rome, Italy.

[9] Walkley and Black. 1934. An examination of the Degtjareff method for determining soil organic matter, and a proposed modification of the chromic acid titration method. Soil Sci., 37:29-38.

[10] Olsen, Cole, Watanabe and Dean. 1954. Estimation of available phosphorus in soils by extraction with sodium bicarbonate. USDA, Circ. 939.

[11] Lu 1999. Analytical methods of soil and agricultural chemistry. Chinese Agricultural Science and Technology Press, Beijing.

[12] Champman. 1965. Cation exchange capacity by ammonium saturation. In: black, C. A., L. E., Ensminger and F. E., Clark (Eds.). Method of soil analysis American Society of Agronomy. Madison Wisconsin, USA. PP. 891-901.

[13] Mehlich. 1984. Mehlich 3 Soil Test Extractant: A modification of Mehlich 2 extractant. Communications in Soil Science and Plant Analysis, 15: 1409-1416.

[14] SAS Institute Inc. 2004. SAS 9.1.2 Qualification Tools User's Guide, Cary, NC.

[15] Sanchez, Villachia, Bandy. 1983. Soil fertility dynamics after clearing tropical rainforest in Peru. Soil Sci Soc Am J. 47:1171-1178.

[16] Chan and Xu. 2009. Biochar: Nutrient properties and their enhancement. In Biochar for environmental management: science and technology. Eds. J Lehmann and S Joseph. pp 67-84.

[17] Shirani H, MA Hajabbasi, M Afyuni and A Hemmat. 2002. Effect of Farmyard manure and tillage system on soil physical proportion and corn yield in central Iran Soil and Tillage Research 68: 101-108.

[18] Abebe Nigussie, Endalkachew Kissi, Mastawesha Misganaw and Gebermedihin Ambaw.2012. Effect of Biochar Application on Soil Properties and Nutrient Uptake of Lettuces (Lactuca sativa) Grown in Chromium Polluted Soils. American-Eurasian J. Agric. \& Environ. Sci., 12 (3): 369-376.

[19] Makhosazana Princess Sika. 2012. Effect of biochar on chemistry, nutrient uptake and fertilizer mobility in sandy soil, Thesis presented in partial fulfilment of the requirements for the degree Master of Science in Agriculture at the University of Stellenbosch.

[20] Vidyavathi G, Dasog S, Babalad HB, Hebsur NS, Gali SK, Patil SG, Alagawadi AR. 2011. Influence of nutrient management practices on crop response and economics in different cropping systems in a Vertisol. Karnataka J. Agric. Sci. 24 (4):455-460.

[21] Bishwoyog Bhattarai, Jasmine Neupane, Surya Prasad Dhakal, Jaya Nepal, Barsha Gnyawali, Ramsharan Timalsina and Ashmita Poudel. 2015. Effect of Biochar from Different Origin on Physio-Chemical Properties of Soil and Yield of Garden Pea (Pisum sativum L.) at Paklihawa, Rupandehi, Nepal. World Journal of Agricultural Research, 2015, Vol. 3, No. 4, 129-138. 